\title{
(-⿶凵⿴囗十)
}

Citation:

Dashper, $K$ (2016) Strong, active women: (Re)doing rural femininity through equestrian sport and leisure. Ethnography, 17 (3). pp. 350-368. ISSN 1466-1381 DOI: https://doi.org/10.1177/1466138115609379

Link to Leeds Beckett Repository record:

https://eprints.leedsbeckett.ac.uk/id/eprint/1216/

Document Version:

Article (Accepted Version)

The aim of the Leeds Beckett Repository is to provide open access to our research, as required by funder policies and permitted by publishers and copyright law.

The Leeds Beckett repository holds a wide range of publications, each of which has been checked for copyright and the relevant embargo period has been applied by the Research Services team.

We operate on a standard take-down policy. If you are the author or publisher of an output and you would like it removed from the repository, please contact us and we will investigate on a case-by-case basis.

Each thesis in the repository has been cleared where necessary by the author for third party copyright. If you would like a thesis to be removed from the repository or believe there is an issue with copyright, please contact us on openaccess@leedsbeckett.ac.uk and we will investigate on a case-by-case basis. 
Strong, active women: (Re)doing rural femininity through equestrian sport and leisure

\section{Katherine Dashper}

\section{Leeds Metropolitan University, UK}

\section{Abstract}

Horse-riding is a popular leisure activity within rural Britain. Straddling two masculinised social contexts - rural, land-based society and sport/physical recreation - horse-riding is a feminised, yet mixed-sex, milieu. This article presents data from an ethnography of the social world of horse-riding to consider how women within this context do and redo gender in ways that may begin to challenge ideas about what women are and are capable of, within rural and sporting contexts. Equestrianism is revealing about elements of rural life, particularly the role of women and women's leisure. Women's active leisure in the countryside has been rendered largely invisible for decades, yet women's sport/physical recreation forms an important part of rural leisure worlds. This study of women and horse-riding offers examples of how feminine identities help shape the rural leisure landscape in ways that begin to redefine gender relations and gender identities within the British countryside in small, yet potentially significant, ways. 


\section{Introduction}

The rural idyll of the British countryside conjures up images of rolling green fields, gentle hills and valleys, drystone walls, bubbling streams and animals grazing the lush grass. For most British people the countryside is valued primarily as "a landscape aesthetic" (Bunce, 1994: 34), representing idealised notions of beauty, simplicity and nostalgia for an imagined past. Animals feature prominently in imagery of the countryside and, in the British context, horses are a common sight in fields and paddocks in rural villages and lining country roads. As Birke and Brandt (2009: 32) argue, "(e)quine blood runs in rivers through Britain's past" and the horse has long played a crucial part in the development of the British nation, with the role of the horse shifting to mirror changes in human society (Goodwin, 1999). Once a vital partner to humans in agriculture, warfare and transport, the modern horse is now predominantly a partner in human sport and leisure. Although accurate figures are not available, there are currently approximately 988,000 horses in the UK, and over 2 million people ride horses each month (BHIC, 2009; BHS, 2012). This article draws on an ethnography of horse riding social worlds to explore this particular aspect of life in rural Britain.

Keeping and riding horses are practises that are often associated with social elites, particularly within Britain (Fletcher and Dashper, 2013). As large herbivores horses need access to relatively big areas of grass to graze and, as the costs of land in Britain are high, the requirement for space has been an insurmountable barrier to horse ownership for many people. However, as the horse has become an animal used 
predominantly for leisure, as opposed to a creature used for work or war, a 'horse industry' has developed that caters for the leisure market (Suggett, 1999; Keaveney, 2008). Horse riding schools providing lessons for adults and children have opened up horse riding as an activity to people without the financial means or land to own a horse. Livery yards offer horse owners the opportunity to rent a stable and access to a field, removing the necessity for owning land. Many of these riding schools and livery yards are now located close to urban areas, offering non-rural residents opportunities to engage in a leisure activity that was once the preserve of rural elites. This has resulted in a relative democratisation of horse riding in Britain: there are now roughly equal numbers of rural and urban horse riders, and riding is much more evenly spread across socio-demographic groups (BHIC, 2009).

Another outcome of the change in use of the horse from a work animal to a leisure animal has been the feminisation of horse riding and the horse industry (Hedenborg and Hedenborg White, 2012; Plymouth, 2012). The origins of modern equestrian sports lie in the military, and so the sports of dressage, show jumping and eventing developed from strongly masculine origins. Although men still perform disproportionately well at the elite levels of these sports, and in the lucrative and high profile equestrian sport of horse racing, at lower levels and among leisure riders, horse riding is a predominantly female activity (Dashper, 2012). Mirroring the situation found in most other western countries, $73 \%$ of riders in Britain are female (BHS, 2012). The feminisation of horse riding offers women many opportunities to demonstrate their physical capabilities, skills and prowess in what was once a strongly male-dominated milieu, as discussed further throughout this article. 
However, although equestrianism offers many opportunities for challenging gender norms and traditional gender roles, gender remains a salient feature of the organisation and experience of horse riding social worlds, both in relation to competitive sport and leisure riding practices (Birke and Brandt, 2009; Dashper, 2012). This article considers how horse riding, as an important aspect of the leisure landscape in rural Britain, both enables and constrains women's gender performances. I begin with a discussion of how femininity and feminine gender identities have somewhat problematic relationships with both the countryside and with sport, two of the key features of equestrianism. This provides a background for considering how gender, and particularly femininity, is negotiated, embodied and sometimes transformed by women involved in the physically demanding countryside sport of horse riding.

\section{Femininity and gender relations in contested terrains}

The ethnography around which this article is based focuses on the social world of the horse yard - places where horses are kept, cared for and ridden. Although the equestrian world is frequently seen as a feminised milieu (Hedenborg and Hedenborg White, 2012), the horse yard is also part of two broader social worlds which are generally conceived to be predominantly masculine spaces - the countryside, and the world of sport/physical recreation. Both of these social worlds are characterised by relatively traditional, normative gender regimes in which men and women, masculinity and femininity, are clearly differentiated and hierarchically 
positioned. I suggest that both rural communities and the institution of sport/physical recreation can be considered 'contested terrains' (Tagg, 2008) because, although historically both represent masculinised spaces in which females and femininities have been marginalised, both are also spaces experiencing change and uncertainty in relation to these long-established conventional gender relations (Bock, 2006; Pfister, 2010). In this section I briefly introduce some of the gender nuances that underpin these social worlds, and consider how this may impact on the experiences of those involved in equestrianism.

Rural societies and communities are deeply gendered. Since the 1970s, the field of rural studies has repeatedly demonstrated the persistence of a dominant ideology that positions men at the head of a 'natural hierarchy' with responsibility for farming and production, and women confined to domestic and subservient roles in the family and local community (see Little and Panelli, 2003). Rural spaces are seen as maledominated and male-defined; places in which definitions of masculinity and what it means to be a 'real' man are bound up with mastery of the land, physical toughness and the denigration of normative feminine traits such as emotion and sensitivity (Bye, 2009). Farming continues to dominate rural societies and communities, even as the economic importance of farming deteriorates in many countries, and to be a 'good' (male) farmer is to dominate and tame the elements, to endure physical toil and extreme conditions, and to demonstrate mastery of the land and landscape (Laoire , 2002; Little, 2002; Saugeres, 2002a; Brandth and Haugen, 2005). In contrast, women's positions in rural societies have often been restricted to supportive and nurturing roles within the family and wider community. Women are often defined by 
their familial bonds - as wives, mothers and/or daughters - and women's work on farms and in other active, land-based occupations is often rendered invisible and unvalued (Brandth, 2002; Reed, 2003; Shortall, 2006; Bryant and Pini, 2009).

Although the literature illustrates the persistent dominance of conventional, (hetero)normative gender relations and identities within rural communities (see Little, 2007), the countryside is experiencing a prolonged period of significant economic, social and cultural change that is having a profound effect on rural societies and the people who live there (Bock, 2006). Decline in the economic significance of farming, coupled with technological changes and innovations, have led to massive changes in the availability, viability and experience of land based rural work (Reed, 2003). Migration of young people to urban areas in search of work and broader social and cultural experiences is threatening the fabric of rural communities (Bye, 2009). The influx of new, affluent residents from urban areas offers a further challenge to traditional rural ways of life (Heley, 2010; Sutherland, 2012). Rural communities are responding to these issues in a variety of ways, but one avenue is through diversification into new sectors and markets to try and secure rural jobs and incomes and, with this, the viability and cohesion of rural communities. The countryside offers many opportunities for tourism and sport and leisure practices, capitalising on natural resources and local heritage - what Garrod et al. (2006) call 'countryside capital' - to appeal to people from urban and rural areas. Rural tourism was often thought of as 'women's work' but the growing importance of tourism and leisure to rural economies and communities has led to more rural men becoming involved in tourism and leisure-related employment 
(Prtrzelka et al., 2005). As a result, once feminised, 'soft' skills related to service are being incorporated into contemporary rural masculinities, alongside more traditional attributes related to being hard, tough and strong (Brandth and Haugen, 2005). Sport and leisure activities, practiced in and through the countryside and rural landscape, also have the potential to begin to redefine rural gender relations and gender identities, and horse riding - as a commonly practiced sport/leisure activity in rural Britain - offers one social milieu in which to consider some of these changes.

Horse riding is an activity that requires physical exertion and skill. Horse riding encompasses formal sports competitions, and non-competitive leisure riding activities, and so is allied to the wider institution of sport - another highly masculinised social space (Clément-Guillotin et al., 2012). Historically most women were excluded from sport and active physical recreation on the spurious grounds that it was unladylike and may damage their reproductive abilities and capacities to be good wives and mothers (Hargreaves, 1994). Although girls and women are now taking part in sport and physical recreation in increasing numbers, and with growing acceptance and visibility, female athleticism is still highly regulated and controlled. Women's physicality is subject to widespread surveillance and social censure, through the media and other social institutions such as schools, gyms and families. Women are encouraged to take part in some physical activity and to mould their bodies in relation to idealised feminine forms - to be slim, toned and shapely (Azzarito, 2009; van Amsterdam et al., 2012). Yet it is a fine line between the desirable, fit feminine form and unacceptable levels of female muscularity and physical strength, and women who cross the boundary of acceptable femininity 
through their sporting practices suffer social censure, such as mocking, ostracism, abuse and lack of support, be that financial or emotional (Messner, 2002; Westbrook and Schilt: 2014).

Consequently, in ways reminiscent of the normative gender identities available to rural women, women involved in sport and physical recreation must perform conventional femininity in order to be accepted - albeit at a subordinate level within the male-defined world of sport (Messner, 2002). Although men are also constrained by restrictive gender norms within sport, and Connell's (1987) concept of hegemonic masculinity has been used to illustrate many of the ways in which involvement in sport can be damaging for some men (e.g. Silva et al., 2012), due to wider gender power relations that position women and femininities as complementary yet subordinate to men and masculinities (Schippers, 2007), women's position within sport is tenuous and acceptance of female athleticism remains limited and conditional (Pfister, 2010). Many women seek to reduce the perceived incompatibility between their sporting abilities and their feminine identities by adopting conventional feminine appearances, by highlighting their involvement in heterosexual relationships and their abilities to still perform feminine roles as care-givers, both in the family and in sports worlds. Women who cannot or choose not to perform normative femininity are marginalised and trivialised, frequently through accusations of lesbianism and/or questioning their female status (Lenskyj, 2003). As Krane (2001: 116) argues, "The underlying message is that athleticism and femininity are contradictory, and females have to go out of their way to show that they can be athletic and be socially accepted." Sport, then, as with the 
countryside, is a masculine, male-defined space in which women are admitted only under certain conditions and always into a subordinate position in relation to men.

There has been limited research exploring sport and leisure in the countryside, and little attention to the intersections between femininity, rurality and sport/physical recreation. The above discussion suggests that women engaging in sport and physical recreation in the countryside may be restricted both by the conventional gender roles and traditional gender relations that characterise rural communities, and by restrictions placed on feminine physicality as expressed through sport and physical recreation. However, as I show in the following sections, this may not always be the case. My ethnography of the predominantly countryside-based sport and leisure world that surrounds horse riding illustrates various ways in which women may begin to challenge some of the gender restrictions and norms of both rural communities and the institution of sport. Although the women in my study were rarely being deliberately subversive to gender norms, women involved in horse riding embody their own forms of femininity, embracing their physical capabilities and sporting prowess, as well as their understanding and management of the land and landscape that is so essential to the keeping and riding of horses, in ways that challenge restrictive and traditional ideas about women and femininity in active rural contexts.

\section{Research approach}


The data presented below is based on an ethnography of the social world surrounding horse riding in Britain, a world that, due to the necessity for large areas of land for horses to graze, has strong links to rural spaces and is part of the fabric of the countryside. The very idea of the 'horse world' is a little misleading, as this social world is fragmented, encompassing a wide range of horse-related activities and horse-keeping practices and situations. However, although there are variations between different practices and activities related to keeping, caring for and riding horses, and different meanings attached to those practices by participants and 'outsiders', there is a common unifying feature - the horse. Latimer and Birke (2009: 2) suggest that "being with horses can itself be performed as a way of life", and indeed my research also suggests that those involved in the social world of horseriding are deeply committed and passionate about horses. The participants in my study invest heavily in equestrianism - financially and, perhaps more importantly, emotionally. Horses and equestrianism matter deeply to these riders, who see riding as an important part of their identities. Thus, whilst acknowledging the limitations of the term, I use the phrase 'the horse world' to signify this milieu that is focused around deep attachment to horses and ponies.

Ethnography has been acknowledged to be a valuable approach to exploring both rural communities and sport and leisure social contexts (Heley, 2010; Trimbur, 2011). In my research of the horse world it was through what Finley (2010: 360) calls "an ethnographic immersion into this subculture" over an extended period of time that I came to gain better understanding of the nuances of the equestrian world. I engaged in participant observation in the 'horse world' over a period of 7 years. As Cassidy 
(2002) found in her research of Thoroughbred racing in Newmarket, my ability to ride and handle horses, and my knowledge of horse terminology and equipment, was an essential element of this project. As a horse owner I was able to engage in routine daily activities of horse care, training, riding, competing and socialising, and I spent many hundreds of hours observing and talking to people about their involvement in equestrianism, recording observations in field notes and through photography. In addition to participant observation I conducted 55 semi-structured interviews with horse owners, including professional riders, amateur competitors in equestrian sport and non-competitive owners who enjoy riding socially. My interview participants included 16 men and 39 women, reflective of female numerical dominance of this social world. Ages of participants ranged from 18-70, but most were over 30 , again reflective of the broad age range of adult participants in horse riding in Britain (BHIC, 2009). Participants were recruited through personal contacts, snowballing, requests on internet discussion forums and via the equestrian press. The interviews enabled me to discuss issues related to keeping, caring for and riding horses in more detail, and worked iteratively with the prolonged period of participant observation as I developed ideas about the 'horse world', its human participants, and, in relation to this article, gender relations within this social world.

Although the social world of horse riding incorporates a wide variety of spaces and places, including competition centres, rural events, open countryside spaces, and online communities, for the purposes of this article my study is framed around the horse yard, the place where horses are stabled on a permanent basis. The yard is the centre of horse worlds. Yards can vary hugely in size, ranging from two or three 
horses up to 50 or more horses, and all the people that accompany this. Regardless of size, however, horse yards share a number of qualities and attributes. The main purpose of the yard is to house horses and so all yards contain something essential to horse sustenance - fields. It is this necessary attribute that ties horse riding and horse culture to the countryside. Horses need space and they need grass, and these are in short supply in urban areas. At the most basic level, in addition to grass to graze on and space to walk around and roll, horses need a clean water supply and shelter from the most severe weather. In Britain, due to poor weather and the shortage of large areas of land to graze, horses also need additional feed (at least in the winter) in the form of hay or haylage. This necessity is a further connection between the horse world and the countryside, and farming specifically. Horses are large consumers of farming produce, in the form of forage (hay, haylage and straw) and other forms of crops for additional feed (such as oats, barley and carrots). In Britain horses are no longer classed as agricultural animals, yet they continue to be closely associated with farming through food, land use and heritage (many farming families own and ride horses and farmers are strongly represented on the British hunting field) (see also Latimer and Birke, 2009). The horse world is thus situated within wider rural communities, with close ties to farming and traditional land-based activities. However, despite these close associations, the horse world is separate to farming, and has different social norms, expectations and values, including those related to gender relations and identities.

Birke et al. (2010: 333) describe horse yards as "small social worlds" and yards are about much more than just the housing and keeping of horses. Many yards provide 
facilities for riding and training - riding arenas, or ménages - and most act as a base from which horse and rider 'hack out' (riding on countryside terrain, be that lanes, tracks, fields, moorland etc.). Importantly though, yards are the social focus of the horse world. Keeping, caring for and training horses is an activity that must be done every day regardless of the weather, other activities, human health or inclination. Horse riding is thus hugely time consuming and for many riders the yard becomes 'a second home'. In ways reminiscent of the family home and the workplace, riders attend the yard very regularly and so social interactions between different horse owners and related people who attend the yard frequently become important features of day to day life. The yard thus becomes an important arena for the performance of gender identities and a site in which gender norms and traditional gender roles related to the countryside and (equestrian) sport/physical recreation are negotiated.

A consideration of gender relations was a key focus for this research. As a feminised, yet sex-integrated, social space, I was interested to consider how gender is performed, negotiated and embodied within the social world of horse-riding. Building on West and Zimmerman's (1987: 127) definition of gender as "the activity of managing situated conduct in light of normative conceptions of attitudes and activities appropriate for one's sex category", I focused on everyday interactions and activities, and the meanings that people give to those practices. Understanding gender norms to "operate by requiring the embodiment of certain ideals of femininity and masculinity" (Butler, 1993: 322), I looked to try and understand if and how individuals within the horse world negotiate these ideals. Connell (2010: 51) 
suggests that "Individuals are held accountable for performing their gender in culturally specified ways" so I sought to try and understand how the specific context of the horse world, and its wider links to both rural communities and the institution of sport, impact upon ways of doing gender in this milieu. While the equestrian social world is often thought to be socially conservative (Fletcher and Dashper, 2013), a number of researchers have suggested that in relation to gender, equestrianism may in fact offer small and subtle challenges to wider restrictive gender regimes (Birke and Brandt, 2009; Plymouth, 2012; Dashper, 2013). In the sections below I use a number of examples to illustrate how involvement in the horse world offers opportunities for gender to be done and, sometimes, 'redone' (West and Zimmerman, 2009; Connell, 2010).

\section{Doing and redoing rural sporting femininities}

\section{Physicality}

Normative representations of rural femininities tie feminine gender roles and identities to the domestic sphere, separating women from the socially valued tasks of working on and managing the land (Little and Austin, 1996; Shortall, 2006). Unlike women who live and/or work on farms, women who work with horses (either as a job, or looking after their own horse) outnumber men and thus women's physical labour in the horse industry is visible (Hedenborg and Hedenborg White, 2013). Keeping horses is labour-intensive. In addition to the physical requirement of riding and training, horse care requires manual labour on a daily basis. Stables need to be 
'mucked out', entailing dirty, heavy work digging beds and pushing loaded wheelbarrows. Bales of straw and hay need to be moved, stacked and lifted, and haynets and water buckets kept stocked. Butler (2013) found that within the highly masculine world of racing, women were thought to lack innate physical abilities necessary to perform stablework. Men in the racing field assumed that women were inherently incapable of performing routine manual work, such as using tools and exerting physical strength. Women who interact with horses on a daily basis provide visible contradictions to these assumptions.

Routine horse care tasks require physical exertion daily, using strength, dexterity and resilience. Women in the horse world revel in their physical capabilities and opportunities to demonstrate that they have strong, powerful bodies. Lucy runs a small livery yard in a rural village and is responsible for the care of 20 horses. Lucy is tall and slim with blond hair worn in a ponytail. She is dressed in jodhpurs - an essential part of any horse woman's wardrobe - and a tight t-shirt. Her appearance thus marks her out as female and she embodies many feminine appearance norms, in relation to her build, her clothes and her hair. Yet she is visibly strong, and her arms and face are tanned and lightly weathered as a result of long hours spent outside in all weathers. Frost (2005) argues that 'doing looks' - visual aspects of the self - is integral to the performance of gendered identity. 'Doing looks' is not an active choice; individuals must engage with beauty norms to some extent because "[a]ppearance constitutes gendered subjectivity" (Frost, 2005: 66). Lucy exemplifies the contradictory ways in which many women in the horse world 'do looks' embodying feminine gender norms through things like hairstyles and clothes, whilst 
simultaneously challenging feminine beauty norms through the physicality of their bodies. Lucy, and many of the women involved in the horse world, is proud of this ambiguity, neither overtly emphasising her femininity or trying to hide her 'unfeminine' muscles and strength (see also Birke and Brandt, 2009; Adelman and Becker, 2013). Lucy is comfortable with her self, proud of how the effects of her physical labour can be seen on her body:

I don't need any expensive gym membership, I don't need a personal trainer to tell me how to work out - just look at these! (She rolls up her sleeves and flexes her bicep, causing the clearlydefined muscles to bulge impressively) I'd tell all those women spending a fortune down at the gyms to come up here and muck out a few stables with me and they'd soon see results, it'd save them a lot of money too!

Lucy is proud of her physical strength and the visible effects this has on her appearance. Muscularity is often perceived to be unfeminine and sportswomen must negotiate the boundary between being strong enough to excel at sport and not becoming 'too muscled' to be considered feminine (Krane, 2001). Lucy ignores this boundary, and proclaims her muscularity as a positive thing. She is proud of the physique that results from her daily manual labour and is glad not to be one of "those women" who pay for gym memberships to try and achieve bodies that resemble hers. 
Women in the horse world thus position their feminine identities in opposition to non-horsey women - women who do not ride horses and engage in the manual labour that accompanies this sport. Many women also frame their feminine identities in opposition to men and masculine identities, particularly in terms of physical strength and embodied physical activities. Julie is in her 30s and keeps her horse at a livery yard. As with Lucy, Julie is proud of how her involvement in manual labour associated with horse care enables her to develop her physicality and demonstrate her strength and physical skills:

Jim (a local farmer) brought the delivery (of hay) today. 200 bales, he brought. And Jim's hurt his arm so he was taking forever unloading the bales, trying to protect his arm and sighing a lot. So I pushed him aside and said 'Listen Jim, I can't wait all day for you to do this simple job, you need some help here, let me show you how it's done" and I had all the bales unloaded and then stacked in the barn while Jim stood there nursing his arm and having a cup of tea!

In Julie's story her female body proves to be stronger and more capable of manual labour than Jim's, refuting the assumptions of many men that women's bodies are not up to the demands of physical labour (Butler, 2013). Rather than assuming a more passive role and getting men to perform physical tasks for them, many women in the horse world regularly take on manual labour with ease. 


\section{Relationships to the land}

In rural communities, masculinity is linked with mastery of and dominance over the elements and nature, whereas femininity is confined to domestic tasks and positions related to caring and nurturing (Little, 2007). Women involved in the horse world embody elements of both masculinity and femininity in relation to their interactions with the land, landscape and nature.

Women's physical labour in relation to horses extends beyond both riding and horse care to encompass elements of land management. Access to grazing land is essential for maintaining horse welfare and well-being. Given the high cost of land and relative shortage of appropriate grazing for horses in Britain, grazing land for horses has to be carefully managed and maintained. Land management is traditionally seen as men's work, and farming masculinity is strongly tied to the ability to tame, control and dominate nature for the benefit of human goals (Saugeres, 2002b). Horse women's knowledge and ability in relation to land management may thus offer a small challenge to traditional to normative gender roles in rural contexts.

Abigail is in her 50s. She has three ponies which she keeps on a large field that she rents from a local farmer. Abigail's ponies are prone to weight gain, which can lead to serious health issues. She therefore has to enforce a system of strip-grazing to limit their intake of grass, but this can lead to deterioration of the field if Abigail does not manage it carefully. This she does do effectively, demonstrating a depth of 
knowledge about grassland management. Abigail seemed to enjoy telling me about her careful approach to land management:

The grass we're on here is 100 -year-old cow pasture and the grass is far too rich for the ponies really, there's too much clover in it, there's the wrong sorts of grasses in a sense, so I have to be careful, they (the ponies) have to be on a strict regime from about March, I've got part of the field that I section off for summer grazing but I leave part of it open for half of the winter so they graze it down, then I close it off for the tail-end of the winter so it's grown a little and it's not too churned up, and that's where I first put them to graze when the spring grass is first coming through and I give them about what, 3 feet by 2 feet of new grass maybe once or twice a day, depending on how rich the grass is and how much weight they're putting on.

Abigail, and many women in the horse world, has an understanding of pasture, growth cycles and how this may affect her horses. These practices are timeconsuming and Abigail manages the strip grazing twice a day, every day, in order to maintain a healthy weight for her animals and to protect the quality of the fields for future use. This has strong resonance with the ways that farmers manage their land and livestock, and suggests a desire and ability to master the natural environment for her own purposes (Little, 2002). 
Birke and Brandt (2009) discuss how even within feminised locales like the world of equestrianism, expertise is gendered male. Masculine domination of nature through farming and other land-based practices is a further example of how expertise is seen as a male preserve in rural contexts (Saugere, 2002b). Although there are lots of examples of how male 'experts' are reified in equestrian contexts (for example through the idea of riding 'masters' who are almost always male, see West and Braganca, 2012), land management offers some women an opportunity to display their depth of understanding and skill. Carrie has four horses which she keeps on a field attached to the back of her house. While Carrie's husband also rides the horses and helps with land maintenance, it is Carrie who has taken the lead in developing their grazing system, based around an American concept called Paddock Paradise (Jackson, 2007). Carrie has sought out knowledge of this paddock management system and is slowly transforming her own small piece of land to try and enact these land management principles:

Well we're just starting out on Paddock Paradise now really, what it is is you actually have a circular route for the horses so they always have to move, it's good for them to keep moving instead of being in a square field, so l'm trying to do it, l'm just starting out really, but it will be going round the outside of the field with trees for shade and different types of ground for their feet, it's good for their joints, and it keeps their weight down too ... we're looking at a two-year project really, cos we can't afford to do it all in one go, we haven't got the money to get diggers in so I'm doing it myself, scooping out 
an area here and putting down pea gravel for them to walk on, and then somewhere else I'm going to have some boulders, all different things, just to keep them moving, keep them interested, and keep the land drained and in good condition.

Carrie is building her expertise in relation to this land management system and the management of her horses' health and well-being, in ways similar to farmers caring for their livestock. Due to a lack of financial resources Carrie is also demonstrating her ability and willingness to do hard, physical labour, as discussed above.

In such ways, traditional feminine roles are done and, to some extent, redone (West and Zimmerman, 2009). Although their expertise may not be comparable with that of many farmers, horse women demonstrate knowledge about the land, and an ability to manage and transform the land to suit their own needs and those of their horses. These women do not accept conventional feminine gender roles, confined to the home and supportive positions in the rural community. Instead, they actively seek out knowledge and the physical skills to take charge of the land they use for their horses.

\section{Caring}

So far I have discussed ways in which horse women can begin to challenge normative ideas about both rural femininity and sporting femininity, through their physical skills and expertise and management of the land. Equestrianism does offer women 
many opportunities to redo feminine gender roles in small ways that open up feminine identities that are active, physically capable and knowledgeable. However, the horse world is not a gender utopia and women in this milieu are still constrained by feminine gender norms that can be less empowering. In both rural and sporting contexts, femininity continues to be defined in relation to caring and nurturing roles (Hargreaves, 1994; Saugeres, 2002b). The horse world is no exception. Many of the examples I have discussed above relate to the practices of horse care, and such care is essential when there is another living creature involved who has physical, emotional and social needs to be catered for. Both men and women must perform elements of horse care. However, 'care' in equestrianism is gendered feminine in ways to similar to many other social contexts where women's emotional work is undervalued and often invisible (Gray, 2009).

Caring and nurturing are commonly believed to be feminine skills, things which women have a 'natural' capacity for. Butler and Charles (2012) show how in the racing field women's role in the stables is belittled in comparison to men through perceived associations between women and caring roles. Women are presumed to enter racing because of 'a natural love of horses', whereas men are thought to enter the field because they want to excel in the sport. This positions women in a caring role, rather than as potential jockeys, and thus associates them with less valued and prestigious feminised practices of caring and nurturing (Butler, 2013). Although the horse worlds I researched are not as male-dominated as racing, women's presumed 'natural' love for horses and affinity for caring still positions women in this field differently to men. 
As a mixed-sex, albeit a feminised, sporting context, both men and women are present in the horse world. A key actor in this milieu is the farrier, who performs the essential job of managing the horse's feet. There is a well known saying in the horse world - 'no foot, no horse' - and this illustrates the importance of good foot care to the horse's well-being and ability to stay sound and thus perform in equestrian sport. Farriery is a highly skilled and physically demanding job. It is also well paid, and farriers hold high status within the horse world. Almost all farriers are men. Horses feet need to be trimmed and, if they wear horse shoes, reshod every 6-8 weeks. This means that farriers are regular visitors to horse yards, and their expertise is highly valued by horse owners. Although in some cases women can begin to claim knowledge and expertise, as in the examples of Abigail and Carrie offered above, the farrier's (and the vet, who is a less regular visitor to the yard) position as expert is unchallenged in the horse world, and many horse owners rely heavily on this expertise. Therefore the male farrier (as expert) and the female horse owner (as horse lover) is a common relationship in the horse world and illustrates a gender dynamic that reflects conventional gender roles and norms. The following example from my fieldnotes is typical of this relationship.

I arrive at the yard and Dom is there, shoeing a horse in the alleyway outside my stable. I say "hi" and walk over to Charlie's (my horse) stable door. Charlie is eating hay so I lean over the door and say hello to him. Dom sighs. "He's not going to answer you, you know." I roll my eyes. Charlie has come over to the stable door, that's an answer to me. 
Dom continues: "You women and your horses. It's all kisses and cuddles and then when I get them I have to shout and smack to get them to behave. For every kiss an owner gives their horse, I have to give them a smack." I roll my eyes again and pat Charlie. . . I return to the stables after riding and Dom is still there, this time shoeing one of the young horses. The horse's foot is balanced on his knee as Dom hammers the nails in. The horse tries to pull back but Dom's strong hands hold onto the horse's foot, steadying him and keeping him in place. "Come on sweetheart, it's ok, there's a good boy," Dom says, calmly. "He can't understand you, you know," I say sarcastically. "He understands me," Dom replies. "Horses know exactly what I mean."

In this exchange my interaction with my horse was belittled by Dom as just an example of "you women" being too soft and caring and treating the horse like a baby. Conversely, when Dom interacted with the young horse he framed his communication in completely different terms. Whereas I was spoiling my horse, his status as an expert farrier meant that his (very similar) communication with the horse could be cast as effective interspecies interaction, and not as a sign of feminine caring. In ways such as this, women's presumed natural proclivities for caring and nurturing are not valued, whereas a male 'expert' performing the same kind of behaviour can be seen as evidence of the masculine attributes of skill, knowledge and expertise. Conventional gender roles are thus reproduced in this kind of encounter and feminine caring is devalued in comparison to masculine expertise. 


\section{Conclusions}

The horse world offers an interesting example for considering femininities and gender identities as this is a social context that straddles two male-defined, masculinised fields: sport and rural society. At the same time, however, the horse world is recognised as a feminised milieu due to strong female dominance. As I have demonstrated throughout this article, this means that the horse world offers women (and men) many opportunities to challenge conventional gender norms and roles and to begin to rework what it means to be a woman within sport, and within rural contexts. The close associations between the horse world, farming and the physical landscape enable women in this field to demonstrate that they are physically strong, capable and competent, and not reliant on men for help with manual labour. The necessity to understand grassland management principles and practices empowers many women in the horse world to develop and exercise traits traditionally valued as masculine - mastery of the land and control of the effects of the elements. Horse women thus begin to carve out sporting countryside femininities that challenge normative expectations about what women are and are capable of.

There are limits to the transformative potential of involvement in the horse world on conventional gender roles and feminine gender identities. Women in this milieu still tend to be positioned as 'natural' carers, and this caring role, when performed by women, is devalued. Additionally, although I have only touched on it briefly in this article, men within this feminised sporting context are more likely than women to be acknowledged as experts and to have their behaviour, knowledge and experience 
valued (Birke and Brandt, 2009). Further, although there are close ties between the horse world and farming, equestrianism is not a part of farming and has a lower status within rural communities. The feminised nature of the horse world may be one factor in the reduced social status of equestrianism in relation to other landbased, masculine practices in the countryside (Andersson and Lehtola, 2011).

However, although these limitations signify the continued subordinate position of women and femininity in relation to men and masculinity in rural and sporting contexts, the horse world does clearly offer opportunities for women to begin to redefine normative gender roles and feminine identities, to some extent. Women in the horse world define their feminine identities in opposition to both non-horsey women and to men, and value their own physical strength and capabilities, and the sense of power this brings. This in itself is an exciting element of the horse world, as even in the twenty-first century culturally dominant norms of femininity still incorporate passivity, docility and physical weakness (in relation to men) as ideals of feminine identity. The horse world demonstrates various ways in which gender is done and redone, in everyday interaction (West and Zimmerman, 2009). Although the examples of challenge to the gender system offered here are in no way revolutionary, and do not threaten the dominance of the gender binary that contributes to male hegemony (Connell, 2010), this does not mean these challenges are insignificant. As Westbrook and Schilt (2014: 53) argue, "Like all other norms and social systems, people create gender. Challenges to the gender system modify rather than break it". Studies such as the one reported on here show ways in which people create gender within their everyday lives. This contributes to understandings of how 
gender is done in everyday interaction as well as how seemingly small, mundane actions may begin to redo gender in ways that may, in concert with other actions, begin to 'modify' the gender system.

Horse riding is an important part of the leisure world of rural communities, and horses form an integral part of the British countryside. This social world has received limited attention from academics to date, yet this study suggests that the horse world is revealing about elements of rural life, particularly the role of women and women's leisure. Women's active leisure in the countryside has been rendered largely invisible for decades, yet women's sport/physical recreation forms an important part of rural leisure worlds. Women's dominant position within the horse world ensures that feminine identities will help shape the rural leisure landscape in ways that may begin to redefine gender relations and gender identities within the British countryside in small, yet potentially significant, ways.

\section{References}

Adelman, M. and Becker, G. (2013) Transition and transgression: Women who ride the rode in southern Brazil. In Adelman, M. and Knijnik, J. (eds.) Gender and equestrian sport: Riding around the world. London: Springer, 73-90. 
Andersson, K. and Lehtoal, M. (2011) Regulating the new equine industry in Finland: Wicked problems, governance models and gendered power structures. Sociologia Ruralis. 51(4): 387-402.

Azzarito, L. (2009). The Panopticon of physical education: pretty, active and ideally white. Physical Education and Sport Pedagogy, 14(1), 19-39.

BHIC (2009) Size and scope of the equine sector. Available from http://www.bhic.co.uk/downloads/sizescope.pdf [Accessed 11/03/11]. British Horse Industry Confederation.

BHS (2012) Equestrian statistics. Available from http://www.bhs.org.uk/ourcharity/press-centre/equestrian-statistics [Accessed 24/09/13]. British Horse Society.

Birke, L. and Brandt, K. (2009) Mutual corporeality: Gender and human/horse relationships. Women's Studies International Forum. 32: 189-197.

Birke, L., Hockenhull, J. and Creighton, E. (2010) The horse's tale: Narratives of caring for/about horses. Society and Animals. 18: 331-347.

Bock, B.B. (2006) Rural gender identities in North and South. In Bock, B.B. and Shortall, S. (eds.) Rural gender relations: Issues and case studies. Wallingford, Oxfordshire: CABI Publishing, 1-15.

Brandth, B. (2002). Gender identity in European family farming: A literature review. Sociologia Ruralis. 42(3): 181-200. 
Brandth, B. and Haugen, M. (2005) Doing rural masculinity: From logging to outfield tourism. Journal of Gender Studies. 14(1): 13-22.

Bryant, L. and Pini, B. (2009) Gender, class and rurality: Australian case studies. Journal of Rural Studies. 25: 48-57.

Bunce, M. (1994) The countryside ideal: Anglo-American images of landscape. London: Routledge.

Butler, D. (2013). Not a job for 'girly-girls': horseracing, gender and work identities. Sport in Society, 16(10), 1309-1325.

Butler, D. (2013) Becoming 'one of the lads': Women, horseracing and gender in the United Kingdom. In Adelman, M. and Knijnik, J. (eds.) Gender and equestrian sport: Riding around the world. London: Springer, 55-72.

Butler, D. and Charles, N. (2012) Exaggerated femininity and tortured masculinity: Embodying gender in the horseracing industry. The Sociological Review. 60: 676-695.

Butler, J. (1993) Bodies that matter: On the discursive limits of 'sex'. New York: Routledge.

Bye, L.M. (2009) 'How to be a rural man': Young men's performances and negations of rural masculinities. Journal of Rural Studies. 25: 278-288. 
Cassidy, R. (2002) The sport of kings: Kinship, class and Thoroughbred breeding in Newmarket. Cambridge: Cambridge University Press.

Clément-Guillotin, C., Chalabaev, A., \& Fontayne, P. (2012). Is sport still a masculine domain? A psychological glance. International Journal of Sport Psychology, 43(1), 6778.

Connell, C. (2010). Doing, undoing, or redoing gender? Learning from the workplace experiences of transpeople. Gender \& Society, 24(1), 31-55.

Connell, R.W. (1987) Gender and power. Stanford: Stanford University Press.

Dashper, K. (2012) Together, yet still not equal? Sex integration in equestrian sport. Asia-Pacific Journal of Health, Sport and Physical Education. 3(3): 213-225.

Dashper, K. (2013) Beyond the binary: gender integration in equestrian sport. In M. Adelman and J. Knijik (eds.) Gender and equestrian sport. Springer: 37-53.

Finley, N.J. (2010) Skating femininity: Gender manoeuvring in women's roller derby. Journal of Contemporary Ethnography. 39(4): 359-387. 
Fletcher, T. and Dashper, K. (2013) 'Bring on the dancing horses!' Ambivalence and class obsession within British media reports of the dressage at the London 2012 Olympic Games. Sociological Research Online. 18(2): 17. 10.5153/sro.3040.

Frost, L. (2005) Theorizing the young woman in the body. Body and Society. 11(1): 63-85.

Garrod, B., Wornell, R. and Youell, R. (2006) Re-conceptualising rural resources as countryside capital: The case of rural tourism. Journal of Rural Studies. 11: 117-128.

Goodwin, D. (1999) The importance of ethology in understanding the behaviour of the horse. Equine Veterinary Journal. 31(S28): 15-19.

Gray, B. (2009). The emotional labour of nursing-Defining and managing emotions in nursing work. Nurse Education Today, 29(2), 168-175.

Hargreaves, J. (1994) Sporting females: critical issues in the history and sociology of women's sport. London: Routledge.

Hedenborg, S. and Hedenborg White, M. (2012) Changes and variations in patterns of gender relations in equestrian sports during the second half of the twentieth century. Sport in Society. 15(3): 302-319. 
Hedenborg, S. and Hedenborg White, M. (2013) From glamour to drudgery:

Changing gender patterns in the equine sector - A comparative study of Sweden and Great Britain in the twentieth century. In Adelman, M. and Knijnik, J. (eds.) Gender and equestrian sport: Riding around the world. London: Springer, 15-36.

Heley, J. (2010) The new squirearchy and emergent cultures of the middle classes in rural areas. Journal of Rural Studies. 26: 321-331.

Jackson, J. (2007) Paddock paradise: A guide to natural horse boarding. Arkansas: Star Ridge Publishing.

Keaveney, S.M. (2008) Equines and their human companions. Journal of Business Research. 61: 444-454.

Krane, V. (2001) We can be athletic and feminine, but do we want to? Challenging hegemonic femininity in sport. Quest. 53(1): 115-133.

Laoire, C. N. (2002). Young farmers, masculinities and change in rural Ireland. Irish Geography. 35(1): 16-27.

Latimer, J. and Birke, L. (2009) Natural relations: Horses, knowledge and technology. The Sociological Review. 57(1): 1-27. 
Lenskyj, H. J. (2003) Out on the field: gender, sport and sexualities. Toronto: Women's Press.

Little, J. (2002) Rural geography: Rural gender identity and the performance of masculinity and femininity in the countryside. Progress in Human Geography. 26(5): 665-670.

Little, J. (2007) Constructing nature in the performance of rural heterosexualities. Society and Space. 25: 851-866.

Little, J. \& Austin, P. (1996). Women and the rural idyll. Journal of Rural Studies,. 12(2): 101-111.

Little, J. and Panelli, R. (2003) Gender research in rural geography. Gender, Place and Culture. 10(3): 281-289.

Messner, M.A. (2002) Taking the field: women, men and sports. Minneapolis: University of Minnesota Press.

Petrzelka, P., Krannich, R.S., Brehm, J. and Trentleman, C.K. (2005) Rural tourism and gendered nuances. Annals of Tourism Research. 32(4): 1121-1137.

Pfister, G. (2010) Women in sport - gender relations and future perspectives. Sport in Society. 13(2): 234-248. 
Plymouth, B. (2012) Gender in equestrian sports: An issue of difference and equality. Sport in Society. 15(3): 335-348.

Reed, M. G. (2003). Marginality and gender at work in forestry communities of British Columbia, Canada. Journal of Rural Studies. 19(3): 373-389.

Saugeres, L. (2002a), Of tractors and men: masculinity, technology and power in a French farming community. Sociologia Ruralis. 42: 143-159.

Saugeres, L. (2002b) The cultural representation of the farming landscape:

Masculinity, power and nature. Journal of Rural Studies. 18: 373-384.

Schippers, M. (2007) Recovering the feminine Other: Masculinity, femininity, and gender hegemony. Theory and Society. 36(1): 85-102.

Shortall, S. (2006) Gender and farming: An overview. In Bock, B.B. and Shortall, S. (eds.) Rural gender relations: Issues and case studies. Wallingford, Oxfordshire: CABI Publishing, 19-26.

Silva, P., Botelho-Gomes, P., \& Goellner, S. V. (2012). Masculinities and sport: the emphasis on hegemonic masculinity in Portuguese physical education classes. International Journal of Qualitative Studies in Education, 25(3), 269-291. 
Suggett, R.H.G. (1999) Horses and the rural economy in the United Kingdom. Equine Veterinary Journal. 31(S28): 31-37.

Sutherland, L.A. (2012) Return of the gentleman farmer? Conceptualising gentrification in UK agriculture. Journal of Rural Studies. 28(4): 568-576.

Tagg, B. (2008) 'Dress as a man': New Zealand men's netball as contested terrain. Ethnography. 9(4): 457-475.

Trimbur, L. (2011) 'Tough love': Mediation and articulation in the urban boxing gym. Ethnography. 12(3): 334-355.

van Amsterdam, N., Knoppers, A., Claringbould, I., \& Jongmans, M. (2012). A picture is worth a thousand words: constructing (non-) athletic bodies. Journal of Youth Studies, 15(3), 293-309.

West, C., and Zimmerman, D. H. (1987). Doing gender. Gender \& society, 1(2), 125151.

West, C., and Zimmerman, D. H. (2009). Accounting for doing gender. Gender and society, 112-122. 
Westbrook, L., and Schilt, K. (2014). Doing gender, determining gender: Transgender people, gender panics, and the maintenance of the sex/gender/sexuality system. Gender and Society, 28(1), 32-57. 